\title{
Level of Accumulated Depreciation of Energy Companies' Assets
}

Maria SIERPIŃSKA ${ }^{1)}$

\footnotetext{
1) Akademia Ekonomiczno-Humanistyczna w Warszawie; email: msierpinska@o2.pl

http://doi.org/10.29227/IM-2021-01-13
}

Submission date: 26-01-2021 | Review date: 28-05-2021

\section{Abstract}

The paper presents the degree of accumulated depreciation of fixed assets in Polish energy companies against the background of global energy companies. The coal-fired energy units used in the Polish energy industry are outdated and require replacement. In the course of the energy transformation, they will be replaced with energy from renewable sources, natural gas and nuclear fuel. The transformation of the energy sector will allow the achievement of climate and environmental goals. Depreciation charged to expense is an internal source of financing for processes of restoration of the production capacity. However, the Accounting Act and the Income Tax Act provide for different methods of calculating depreciation, which means that not all depreciation is tax-deductible and that it does not reduce the tax base. Reducing the discrepancies in legal solutions regarding the calculation of depreciation in companies may stimulate the implementation of the processes of energy transformation.

Keywords: depreciation, average depreciation rate, accumulated depreciation of assets

\section{Introduction}

Fixed assets used by a given entity in the course of its business activity are subject to wear and tear over time. The entity must earmark funds for their replacement. This is done by systematically charging the depreciable amount to expense in the entity's profit and loss account/income statement. Depreciation becomes an expense but does not entail immediate expenditure so as to replace a given asset. Thanks to depreciation, the company can recover in instalments the capital it tied up in its assets. This capital can then be used to finance current investments or to service debt incurred to finance investment. Therefore, depreciation cannot be considered in isolation from the entirety of the company's activity. By being an expense for the company, depreciation can be used to control the company's profit/loss. An increase in the costs allows the company to post a lower net profit divided by shareholders during their General Meeting between a part consumed by themselves and a part retained to fund development. Depreciation can also be used as an instrument facilitating the control of the level of tax liabilities and the size of the financial surplus in specific periods. It is used to service debt, hence it is of interest to the providers of external capital.

The paper aims to assess the level of accumulated depreciation in energy companies from the angle of the need to replace their coal-based production capacity with a capacity based on renewable energy sources. The working hypothesis guiding this research holds that the level of fixed asset depreciation in Polish energy companies is higher than in global energy companies, which will accelerate the transformation of the Polish energy sector.

Depreciation as a reflection of the degree of assets' wear and tear

Fixed assets used in the pursuit of business activity are subject to systematic degradation, which reduces their value in use or exchange value. Pertinent literature recognises various reasons for a decline in assets' value in use. The decline may be gradual over an asset's useful life, or sudden as a result of excessive dynamic workload of a thermal, mechanical or chemical nature, or it may result from a failure. The physical degradation of fixed assets occurs as a result of their use in production, service and other economic activity processes. According to (Martyniuk, 2008), the relationship between the scale and rate of this wear and tear results from an interplay of:

- physical and chemical properties of the fixed assets concerned,

- the age of the fixed assets,

- intensity and conditions of use,

- frequency, method and scope of repairs.

An asset may be physically fit for uninterrupted use, but its degradation due to economic influences may rule out such exploitation. The obsolescence of fixed assets is caused by technical and technological progress leading to the emergence of assets with better technical and operational parameters. These new assets are superior and make it possible to increase labour productivity and manufacture products better and more cost effectively. The obsolescence of fixed assets results in the loss of their value in use before they reach the end of their physical life.

The wear and tear of fixed assets is reflected in accounting records. Accounting recognises two meanings of wear and tear of a fixed asset (Szczypa, 2011):

- accumulated depreciation showing the decrease in the initial value of the fixed asset,

- depreciation, which is an element of a product's manufacturing costs for the company.

Depreciation spreads the value of a depreciable fixed asset over its useful life and charges it to the company's expenses in order to recoup the expense incurred to obtain it, thereby creating a fund for its replacement after its life ends. The 
Tab. 1. Degree of accumulated depreciation of tangible fixed assets and intangible assets in selected energy companies in 2015-2019. Source: own calculations based on information in the balance sheets of the analysed companies obtained from a Reuters database.

Tab. 1. Stopień umorzenia rzeczowych składników majątku trwałego i wartości niematerialnych i prawnych w wybranych spółkach energetycznych w latach 2015-2019

\begin{tabular}{|c|c|c|c|c|c|}
\hline Name of company & 2015 & 2016 & 2017 & 2018 & 2019 \\
\hline Enea & 35.18 & 35.97 & 35.63 & 36.89 & 38.97 \\
\hline Energa & 33.49 & 37.34 & 38.92 & 38.91 & 40.23 \\
\hline PGE & 45.25 & 44.83 & 42.40 & 43.01 & 49.14 \\
\hline Tauron Polska Energia & 37.86 & 39.66 & 40.30 & 41.60 & 42.34 \\
\hline Iberdrola & 38.65 & 38.72 & 39.65 & - & 39.45 \\
\hline NextEra Energy Inc. & 23.58 & 23.10 & 22.74 & 23.58 & 23.36 \\
\hline SSE PLC & 43.53 & 45.98 & 49.38 & 49.66 & 47.66 \\
\hline Valero Energy Corp. & 27.65 & 29.84 & 31.32 & 32.08 & 32.94 \\
\hline Xcel Energy Inc. & 33.41 & 33.52 & 34.50 & 32.85 & 31.68 \\
\hline
\end{tabular}

initial value of the fixed asset is the basis for calculating depreciation. The initial value is its purchase price, the cost of its manufacturing or construction if the fixed asset is made in-house, fair (market) value if the fixed asset is received as an inheritance, donation or otherwise on a free-of-charge basis. In the case of leasing, its initial value is stated in the leasing contract (Aleszczuk, 2012). The initial value of fixed assets may change in the course of their exploitation as a result of their improvement or modernisation as well as due to the official revaluation of fixed assets.

The method of calculating depreciation amounts charged to expense is regulated by provisions of the Accounting Act and the Corporate Income Tax Act (CIT). The Accounting Act allows economic entities to both autonomously determine depreciation rates and to choose the depreciation method. Moreover, it indicates that in selecting the depreciation rate and method, the economic useful life of the fixed asset should be taken into account as the first priority. Pursuant to article 32 of the Accounting Act, the economic useful life is determined in particular by:

- the number of shifts worked by the fixed asset;

- the pace of technological and economic progress;

- fixed asset's productivity measured in terms of the number of hours worked or the number of manufactured units or any other appropriate measure;

- legal or other restrictions on the use of the fixed asset;

- the net selling price of a significant remainder of the fixed asset anticipated at liquidation.

"In the part relating to depreciation, the Corporate Income Tax Act sets out the principles underpinning the determination of depreciation for the purposes of calculating income tax, and it does so in a more restrictive way than the Accounting Act. The lawmaker provided for the possibility for companies of using various depreciation methods for tax deductible costs" (Cygańska, 2014). The provisions of this act show that entrepreneurs can choose from among three depreciation methods (Iwin-Garzyńska, 2012):

a) one-off

b) linear, using standard, increased or reduced deprecia-

tion rates as specified in the Schedule to the Act,

c) linear, using individualised depreciation rates,

d) declining balance

The one-off depreciation method involves one-time recognition of the value of the acquired fixed asset as a tax deductible cost. As a rule, the right to one-off depreciation is granted to small taxpayers or taxpayers starting business activity and is applied to fixed assets from group 3-8 of the Classification of Fixed Assets (KŚT) (other than passenger cars) in the tax year in which these assets are recorded in the register of fixed and intangible assets, up to a value not exceeding the equivalent of the limit on the aggregate value of such depreciation in the given year. In 2021, the deductible amount totals 50000 euro. (Kuchta, 2021). The linear method means depreciation made in equal monthly or quarterly instalments. It also is the primary depreciation method for tax purposes. The depreciation is made from the first day of the month following the month in which the fixed asset is recorded in the register. With regard to this method, the lawmaker allows the possibility for companies to apply higher and lower depreciation rates relative to the standard rates included in Schedule 1 to the Act. Moreover, in certain cases it is possible to use individualised depreciation rates. Increased depreciation rates can apply to:

- buildings and structures used in: demanding conditions - coefficients of 1.2 or less can be used, and poor conditions - coefficients of 1.4 or less can be used;

- machines, equipment and means of transport, except for marine vessels, used more intensively relative to average conditions or conditions requiring exceptional technical efficiency - coefficients of 1.4 or less can be used for such periods;

- machines and equipment from groups 4-6 and 8 (KŚT), based on separate regulations, subject to rapid technological progress - coefficients of 2.0 or less can be used.

The company has the option to lower the depreciation rate specified in the schedule to the act, however, as a result, the income tax base rises. The possibility to increase or lower the depreciation rates is an expression of the principle of flexibility of the tax regime. It is one of the basic principles underlying the construction of a common consolidated tax base and the concept of harmonisation of income taxes across the European Union. On the other hand, solutions are being sought to support standardisation and objectification of tax income determination, and consequently easier comparison of tax burdens.

The current system of fixed asset depreciation enables companies to apply individual depreciation rates for improved or second-hand components of fixed assets. The rates for these assets are set by the company itself, but the depreciation period resulting from the rate it applies must not be 
Tab. 2. Age structure of Poland's distribution network in 2019, in percentage. Source: Forum Energii, M. Janik Sieć dystrybucji prądu należy utkać od nowa Rzeczpospolita, Ekonomia \& rynek 15 July 2019, p. A20

Tab. 2. Struktura wieku sieci dystrybucyjnej w Polsce w 2019 roku, w proc. Źródło: Forum Energii, M. Janik Sieć dystrybucji prądu należy utkać od nowa Rzeczpospolita, Ekonomia \& rynek 15 July 2019, p. A20

\begin{tabular}{|l|r|r|r|r|}
\hline Type of line & Over $\mathbf{4 0}$ years & $\mathbf{2 5}-\mathbf{4 0}$ years & $\mathbf{1 0 - 2 5}$ years & Under 10 years \\
\hline HV overhead lines & 42 & 34 & 15 & 9 \\
\hline HV cable lines & 3 & 0 & 17 & 80 \\
\hline HV/MV stations & 30 & 33 & 20 & 17 \\
\hline HV/MV transformers & 19 & 33 & 19 & 29 \\
\hline MV overhead lines & 37 & 39 & 17 & 7 \\
\hline MV cable lines & 16 & 24 & 28 & 31 \\
\hline MV/LV stations & 28 & 32 & 22 & 19 \\
\hline MV/LV transformers & 15 & 29 & 25 & 31 \\
\hline Overhead lines & 31 & 35 & 21 & 13 \\
\hline LV cable lines & 13 & 25 & 31 & 31 \\
\hline
\end{tabular}

shorter than that specified in the pertinent act in respect of the individual groups of fixed assets. Apart from the linear method, Polish tax regime permits the use of the accelerated, declining balance method. It assumes decreasing depreciation charges resulting from the declining usefulness of the fixed asset over the course of time of use. This is due to the assumption that the fixed asset ages over time, which means that it is less productive and requires increasingly frequent maintenance and repairs. The amount of annual depreciation in the first years of use is higher than the annual depreciation under the linear method and in subsequent years it becomes lower and lower. Accelerated depreciation of fixed assets in the first years of its operation stimulates the company to use them intensively when they are still new and technically efficient.

The declining balance method is considered to be a form of tax preference, as increased depreciation reduces the company's taxable income and, consequently, also its income tax payable. Accelerated depreciation of a declining balance nature may be applied to machinery and equipment classified as groups 3-6 and 8 according to the Central Statistical Office classification of fixed assets and to means of transport other than passenger cars. Pursuant to the provisions of the Act, in the first year of exploitation of the fixed asset, the company uses the depreciation rates stipulated in the list, increased by a factor of 2 or less. The factor of increase in the depreciation rate used under the declining balance method may not exceed 3 , but only in the case of fixed assets that may be depreciated under this method. The above holds for funds in a plant located in a commune with a particular risk of high structural unemployment, or in a commune threatened by recession and social degradation. In the subsequent tax years, depreciation is made from the net (present) value determined at the beginning of subsequent years, i.e. from the gross initial value less depreciation charges to date. However, starting from the tax year in which the annual depreciation amount so determined would be lower than the annual depreciation amount calculated using the straight-line method (without the adjustment factor), the company makes further depreciation using the linear method. The regulations on the declining balance method also contain preferential provisions for start-up entrepreneurs and for 'small taxpayers'. These entrepreneurs can use depreciation including one-off depreciation of up to $100 \%$ of the initial value of the fixed asset in the first tax year (Article $16 \mathrm{k}$ of the Act). This applies to fixed assets from groups 3-8 (KŚT), including machinery, equipment and means of transport other than passenger cars.

\section{Research method}

Financial statements of listed energy companies were sourced from a Reuters database. Based on information in the statements, the ratios showing the degree of depreciation of tangible fixed assets and intangible assets as well as the average annual depreciation rate for these assets were calculated. The degree of asset's accumulated depreciation was calculated as the ratio of the aggregate depreciation to the gross value of depreciated assets at the end of the calculation period. The average annual depreciation rates for these assets are the ratio of the annual depreciation to the gross value of the depreciated assets. At PGE, the globally reported depreciation level also included impairment charges. In 2016-2019, large write-off were made on account of revaluation of assets used, which upset the comparability of the analysed values. In order to ensure the comparability of data, the amount was verified and the average annual depreciation ratio was calculated taking into account only the accrued depreciation.

It should be added that the level of the calculated ratios was influenced by changes in accounting principles and the implementation of new global financial reporting standards into accounting practice. The biggest changes were caused by the implementation of IFRS 16 Leases in 1 January 2019. The new IFRS 16 changed the rules for recognising contracts defined as leases. The main change involves the departure from the split between financial lease and operating lease for the lessee. All lease contracts came to be treated as finance leases and were recognised in the balance sheet, while prior to the implementation of the standard, the property used under operating lease contracts was not recognised in the balance sheet. In addition, the value of lease, rental, lending and similar agreements came to be assessed. These values were discounted and their current value was incorporated into the balance sheet.

\section{Degree of accumulated depreciation of fixed assets in en- ergy companies}

Table 1 shows the degree of accumulated depreciation of tangible fixed assets and intangible assets in energy companies. The figures in the table indicate a relatively high level of accumulated asset depreciation in Polish energy companies - it ranges between 35 and $45 \%$ of their production capacity. The companies are burdened with outdated production capacities in which coal is the energy carrier. Over $70 \%$ of energy generating units are over 30 years old and they will have to be decommissioned in the next 20 not only because of the climate policy, but mainly because of their obsolescence 
Tab. 3. Average annual depreciation rate for tangible fixed assets and intangible assets in selected energy companies in 2015-2019. Source: own calculations based on the balance sheet data for analysed companies sourced from a Reuters database

Tab. 3. Średnioroczna stopa amortyzacji rzeczowych składników majątku trwałego i wartości niematerialnych i prawnych w wybranych spółkach energetycznych w latach 2015-2019

\begin{tabular}{|c|c|c|c|c|c|}
\hline Company name & 2015 & 2016 & 2017 & 2018 & 2019 \\
\hline Enea & 2.97 & 3.81 & 3.70 & 4.36 & 4.29 \\
\hline Energa & 4.58 & 4.46 & 4.33 & 4.03 & 4.20 \\
\hline PGE & $\begin{array}{r}4.87 \\
13.72 * \\
\end{array}$ & 4.15 & 3.94 & 3.52 & $\begin{array}{r}3.41 \\
9.46^{*}\end{array}$ \\
\hline Tauron Polska Energia & 4.37 & 3.65 & - & 3.52 & 3.44 \\
\hline Iberdrola & 3.28 & 2.84 & 4.11 & - & 3.37 \\
\hline NextEra Energy Inc. & 3.99 & 3.94 & 2.82 & 4.49 & 4.16 \\
\hline SSE PLC & 7.09 & 4.70 & 4.23 & 3.05 & 3.92 \\
\hline Valero Energy Corp. & 4.99 & 5.02 & 4.96 & 4.87 & 4.94 \\
\hline Xcel Energy Inc. & 2.74 & 2.99 & 3.25 & 3.36 & 3.37 \\
\hline
\end{tabular}

cluding revaluation write-offs on fixed assets, which are reported in the cash flow statement together with Ireciation.

(Boroń, 2021). The programme of rebuilding the energy sector assumes the elimination of these capacities and a transition to alternative eco-friendly energy sources.

The balance sheets of SSE PLC were as of 31 March, hence the figures for each year cover a period of 1 April-31 March of the following year.

A degree of asset depreciation similar to that of Polish companies is reported by the Spanish company Iberdrola and the British-Irish company SSE PLC. The American energy company NextEra Energy Inc. which produces energy from alternative sources has the lowest level of asset depreciation consistently staying at below $25 \%$. Notably, accumulated depreciation levels of assets were systematically rising across all Polish energy companies. In PGE they exceeded 49\% in 2019. This year, the company reported exceptionally high impairment losses on assets - PLN 7518 million (Note 7.2.1. to the statements). Coupled with depreciation, these 2019 write-offs amounted to PLN 11417 million, while PGE's depreciation of PLN 3985 million was comparable to that of the previous year when it totalled PLN 3893 million. Recognition of such high revaluation write-offs resulted in a loss of PLN 3928 million. In 2018, the company generated PLN 1511 million in profit.

Apart from outdated production capacities, Polish energy companies are also saddled with an outdated power grid. Only one in five kilometres of the network is less than 25 years old. An overhead line-based power grid predominates. Cables account for approximately $20 \%$ of the power grid. The increasingly extreme weather phenomena (e.g. heavy snowfall in January 2021) have an adverse effect on power lines, causing them to break. Most of these networks at the transformer station level require investments in safety instrumentations solutions. The age structure of Poland's energy distribution network is presented in Table 2 .

$42 \%$ of high-voltage overhead lines are over 40 years old and $76 \%$ are over 25 years old, and a further $63 \%$ of $\mathrm{HV}$ and MV stations are over 25 years old. Only $24 \%$ of MV overhead lines are less than 25 years old. M. Janik (2019, p. A20) contends that the state of the national transmission system is similar to that of such European countries as Germany, France and Austria. However, the pace of planned modernisation in these countries is much higher than in Poland. Industry 4.0 requirements demand rapid network modernisation. It becomes necessary to implement intelligent systems controlling network parameters, to build insulated lines, use modern energy storage technologies, which may be a reasonable alternative to building new lines. The development of electromobility and the connection to the grid of an ever greater number of dispersed energy sources also require investment in the distribution network. It is necessary to expand the power grid in the north of the country, including to connect offshore wind farms and distribute energy around the country.

Changes in the principles underlying calculation of depreciation had an impact on the increased level of depreciation and the accumulated depreciation of assets in Polish energy companies. The companies analysed different types of contracts to see whether a given contract includes a lease. Pursuant to the definition of IFRS 16, leasing contracts in energy companies include:

- perpetual usufruct of land - both purchased and received in kind, or received free of charge on the basis of an administrative decision,

- land and transmission easements,

- lease and hire agreements, etc. related to the location of line and technical infrastructure (heating nodes, transformers),

- hire and lease agreements, etc. of office premises,

- hire and lease agreements etc. of buildings, structures and technical equipment.

The value of assets was affected the most by the recognition of perpetual usufruct of land and land hire/lease agreements, which, before the entry into force of IFRS 16, were recognized as operating leases. Not all contracts were treated as solutions subject to the provisions of IFRS 16, though. For example, following careful analysis, PGE concluded that the scope of IFRS 16 does not cover contracts for the occupation of a road lane for the purposes of placing energy infrastructure, for which a significant replacement right was found to apply, or contracts of lease of links/optical fibres/power cable ducts. In the case of easement contracts for the laying of overhead infrastructure, the non-leasing component (overhead line) constitutes the dominant element of such contracts. The share of the leasing component (pole/pylon) is immaterial. Decisions regarding the occupation of a road lane generally fall within the scope of the provisions of a definition of a lease. However, within the PGE Capital Group, wherever there are 
cases of the road administrator using the legally mandated right to request relocation of infrastructure laid along the road lane, its companies do not enjoy the full right to manage the use of the identified asset. In this case, the contracts do not satisfy the provisions of the definition of a lease. In the case of lease agreements for links/optical fibres/power cable ducts, the Group does not use most of the production capacity of the asset. Consequently, in accordance with IFRS 16 the asset does not fulfil the criteria of an identified asset, and the above-mentioned contracts (e.g. a contract for the lease of capacity on a fibre optic line) do not fall within the scope of the definition of a lease. On the other hand, in the case of easement agreements for the laying of overhead infrastructure, the dominant element of the agreement is constituted by the non-leasing component (overhead line). The share of the leasing component (pole/pylon) is immaterial. Easement agreements generally meet the definition of lease covered by IFRS 16, however, due to their insignificant impact on the value of assets, they were recognised as lease in accordance with IFRS 16 (PGE Consolidated Report, p. 38).

\section{Average rates of asset depreciation}

The possibility of replacing a company's assets is determined by the level of the selected depreciation rates. These show the intensity of assets' use, which affects the level of their productivity. Table 3 shows the average depreciation rates in energy companies - these were calculated as a ratio of accrued annual depreciation to the gross value of depreciated assets. They are relatively low, ranging between 2.5 and $5.0 \%$ of the gross value of the depreciated fixed assets. This is due to the structure of the fixed assets held, dominated by buildings, structures and electricity transmission networks that have a very long useful life.

The balance sheets of SSE PLC were as at 31 March, hence the figures for each year cover a period of 1 April - 31 March of the following year.

During the study period, the average depreciation rates increased in three companies (Enea, NextEra, Xcel Energy Inc.), while Tauron, SSEplc and PGE reported a decrease caused by the termination of depreciation of certain assets and a low level of new investments.

However, the investment needs of Polish energy companies are much greater than those of global companies. Poland's coal-powered electricity production increases $\mathrm{CO}_{2}$ emissions. Under Poland's energy policy until 2040, in 2040, coal is to generate $11-28 \%$ of electricity depending on $\mathrm{CO}_{2}$ prices. There are plans involving the construction of a nuclear power plant and an increase in energy production from renewable sources, including from wind farms, photovoltaics, biogas and hydrogen. This means that huge capital outlays are required to transform the energy sector in Poland and eliminate obsolete coal-fired energy units and transmission networks.

\section{Conclusions}

In summary, it should be emphasised that the hypothesis formulated in the introduction to the paper has been confirmed. The degree of accumulated depreciation of fixed assets in Polish energy companies is higher than the same in global energy companies. Obsolete coal-based production capacities predominate. The energy transmission network is similarly outdated. In the coming years, Poland will have to undergo an energy transformation involving not only the elimination of obsolete coal-fired power units, but also adjustment to EU requirements for climate and environmental protection. In December 2020, the European Council reached agreement on increased greenhouse gas emissions reduction target from $40 \%$ to $55 \%$ by 2030 . In the new financial perspective, Poland will receive PLN 130 billion in the form of grants. More than one third of this amount should be allocated to financing environmental and climate projects. The most important projects will include: development of renewable energy sources, energy efficiency, digitisation of the energy sector and clean heat (heating networks and heating). Projects in the area of heat engineering should be a priority, as it is one of the important operating segments of Polish energy companies. Energy companies operate coal-fired heating plants, which were built in the seventies and eighties, and are now outdated. Additionally, $\mathrm{CO}_{2}$ emissions charges are increasing, which will accelerate transformation in the heating industry. In the course of transformation of the Polish energy and heating industry, the country's energy security should be the underlying factor of the decision-making process. The development of energy generation based on alternative energy sources will require the implementation of flexible capacities around natural gas. It should be noted that investments in the energy sector will stimulate the development of the Polish economy and accelerate recovery from the economic crisis. 


\section{Literatura - References}

1. Aleszczyk J. 2012). Rachunkowość finansowa od podstaw. Ed 6. Poznań, Zysk i S-ka.

2. Boroń M.(2021). Kurtyka : w ciągu dwóch dekad wyłączymy 70 proc. starych bloków energetycznych,

3. https://www.msn.com/pl-pl/finanse/najpopularniejsze-artykuly/kurtyka-w-ciągu-dwóch-dekad-wyłączymy-70proc-starych-bloków-energetycznych/ar-BB1cqyKT?ocid=spartan-dhp-feeds 3.01.2021.

4. Cygańska M. (2014). Wpływ alternatywnych metod amortyzacji środków trwałych na wynik finansowy, nadwyżkę finansową i obciążenia podatkowe przedsiębiorstwa - analiza przypadku, Zeszyty Naukowe Uniwersytetu Szczecińskiego, No. 832, Finanse, Rynki Finansowe, Ubezpieczenia, No. 71, pp. 9-18.

5. Janik M. (2019). Sieć dystrybucji prądu należy utkać od nowa, Rzeczpospolita, Ekonomia \& rynek 15 July 2019 , p. A20.

6. Kuchta A. (2021). Jednorazowa amortyzacja w 2021 roku, https://ksiegowosc.infor.pl/ achunkowość/amortyzacja/4699340,Jednorazowa-amortyzacja-w-2021-r.html 5.01.2020

7. Martyniuk T. (2008). Rachunek amortyzacji środków trwałych w przedsiębiorstwie. ODDK, Gdańsk.

8. Szczypa P. (red.) (2011). Rachunkowość finansowa. Ed. 3. CeDeWu Warszawa.

9. International Financial Reporting Standard 16 Leases file://C:/Users/maria/AppData/Local/Packages/Microsoft. MicrosoftEdge_8wekyb3d8bbwe/TempState/Downloads/MSSF\%2016\%20Lesing\%20(1).pdf 2.01.2021.

10. PGE Polska Grupa Energetyczna Skonsolidowane sprawozdanie finansowe za rok 2019. https://www.bankier.pl/ static/att/emitent/2020-03/Skonsolidowane_sprawozdanie_finansowe_GK_PGE_2019_202003312037274072.pdf 2.01.2021.

11. Accounting Act of 29 September 1994 as amended. Uniform version 2019, item. 1495; Journal of Laws 2019 r., item 1571; Journal of Laws 2019 r., item 1680; Latest amendment: Journal of Laws 2020 item 568)

12. https://ksiegowosc.infor.pl/rachunkowosc/amortyzacja/4699340,Jednorazowa-amortyzacja-w-2021-r.html 5.01.2021.

13. Act of 15 February 1992 on corporate income tax, i.e. of 18 August 2020 - Journal of Laws 2020 item 1406 (latest amendment: Journal of Laws 2020 item 1565),

14. https://ksiegowosc.infor.pl/rachunkowosc/amortyzacja/4699340,Jednorazowa-amortyzacja-w-2021-r.html 5.01.2021

\section{Abstrakt}

W artykule zaprezentowany został stopień umorzenia środków trwałych polskich spółek energetycznych na tle światowych koncernów energetycznych. Wykorzystywane w polskiej energetyce bloki weglowe sa przestarzałe i wymagaja wymiany. W wyniku transformacji energetycznej będa one zastępowane energią z odnawialnych źródeł, gazu i paliwa jądrowego.

Transformacja energetyki pozwoli na realizację celów w obszarze klimatu i środowiska. Naliczana w ciężar kosztów amortyzacja stanowi wewnętrzne źródło finansowania procesów odtwarzania mocy produkcyjnych. Jednak przepisy ustawy o rachunkowości i ustawy o podatku dochodowym różnicują sposób naliczania amortyzacji co powoduje że nie zawsze cała amortyzacja stanowi koszt uzyskania przychodu i nie pomniejsza podstawy opodatkowania. Ograniczenie rozbieżności w rozwiązaniach prawnych dotyczacych naliczania w przedsiębiorstwach amortyzacji może wplynąć stymulująco na realizację procesów transformacji energetycznej.

Słowa kluczowe: amortyzacja, średnia stopa amortyzacji, skumulowane umorzenie majątku trwałego 